\title{
GENETIC DIVERSITY AND TRAIT ASSOCIATION ANALYSIS OF INDONESIAN RICE (Oryza sativa L.) GERMPLASM USING SSR MARKERS
}

\author{
FATIMAH*, LINA HERLINA and TIUR SUDIATY SILITONGA \\ Indonesian Center for Agricultural Biotechnology and Genetic Resources Research and Development, \\ Bogor 16111, Indonesia
}

Received: 26 May 2015/Accepted: 4 July 2016

\begin{abstract}
Generating a new crop variety with certain desirable traits requires germplasm collection with wide genetic diversity to facilitate accelerated development of improved cultivars. This study was conducted to characterize genetic diversity of Indonesian rice accessions using SSR markers and their agro-morphological characters to allow the identification of Marker Trait Association (MTA). A survey of genetic diversity among 72 traditional landraces of 15 provinces in Indonesia and 24 improved varieties was conducted using four multiplex panels of 14 fluorescent-labeled SSR markers and 22 agro-morphological characters. A total of 140 alleles with an average of 10 alleles per locus and Polymorphism Information Content (PIC) values at 0.73 . The population structure identified five subgroups. A total of 4 highly significant MTA were identified. One character with highly significant MTA was number of panicle associated with RM277. Based on SSR marker, RM105 had two MTAs for auricle color and ligule shape. After validation, these MTAs may be deployed to improve rice productivity.
\end{abstract}

Keywords: Genetic diversity, Indonesian rice, Marker-Trait Association, SSR

\section{INTRODUCTION}

Through various exploration missions, more than 4,000 rice germplasms consisted of landraces, elite lines, high yielding varieties, introduced variety/lines as well as 88 accessions of wild rice species are kept in Indonesian Center for Agricultural Biotechnology and Genetic Resources Research and Development (ICABIOGRAD). They have very important role as genetic resources. In breeding program to create high yielding varieties of food crops, it is important to carry out characterization and evaluation of germplasms to increase utilization of genetic resources (Silitonga et al.2001, Silitonga 2010).

Agro-morphological characterization of germplasm accessions is fundamental in order to provide information for plant breeding programs (Lin 1991, Nascimento et al. 2011). Systematic study and characterization of collected germplasms are not only important for utilizing

\footnotetext{
* Corresponding author: fatimahsuw@gmail.com
}

the appropriate attribute based on donors, but also essential in the present era for protecting the unique rice. Thus, there is a need to collect, exploit and evaluate the untapped germplasm (Parikh et al. 2012). Identification of cultivars with distinct morphological traits facilitates high resolution QTL mapping and validates candidate genes responsible for quantitative agronomical characters (Li etal. 2010).

The advantage of using fluorescent-labeled microsatellite markers for genetic diversity analysis in rice with multiple dyes allows efficient genotyping using multiplex panels of markers (Blair et al.2002, Coburn et al. 2002, Jain et al. 2004, Thomson et al. 2007). The use of capillary electrophoresis provides additional benefits, including greater automation, ease of use and precision in fragment sizing, which makes it the preferred technology for Simple Sequence Repeat (SSR) genotyping in rice (Lu et al. 2004, Garris et al. 2005, Thomson et al.2007). Previous study carried out on genetic diversity and population structure of Indonesian germplasm characterized 330 rice 
accessions, including 246 geographically-diverse Indonesian landraces and 63 Indonesian improved cultivars, using capillary electrophoresis with 30 fluorescent-labeled microsatellite markers (Thomson et al.2007).

Several researchers reported the use of agromorphological markers combined with SSR markers in the characterization and study of rice (Oryza sativa L.) germplasm diversity. Using 42 agro-morphological characters associated with 39 SSR markers, Bajracharya et al. (2006) examined genetic relationships among 147 high altitude rice landraces from Nepal. Agrama et al. (2007) identified SSR markers associated with agronomically important phenotypic traits using 92 rice germplasm accessions evaluated for yield and kernel characteristics; when being genotyped with 123 SSR markers it was shown that many of the associated markers were located in regions where QTL had previously been identified. Seetharam et al. (2009) characterized 30 rice genotypes comprising landraces, pure lines, somaclones, breeding lines and varieties specifically adapted to costal saline environments using SSR markers and morphological characters.

The objectives of the present study were to characterize genetic variation of 96 rice accessions using SSR markers and agro-morphological characters allowing identification of marker trait association and to provide useful information to facilitate rice plant breeding programs.

\section{MATERIALS AND METHODS}

Seeds of 72 Indonesian rice landrace accessions originated from 15 provinces were obtained from Indonesian Center for Agricultural Biotechnology and Genetic Resources Research and Development (ICABIOGRAD). Twentyfour cultivated varieties were added from Indonesian Center for Rice Research, Agency for Agricultural Research and Development (IAARD), Indonesia Ministry of Agriculture. The control variety used in this study was Inpari 1 for indica. Inpari 1 was improved variety originated from IR64 and IRBB7 which developed for resistance to leaf blight disease. It was developed by conventional breeding method, while rice variety code was developed using marker assisted selection (Bustamam et al. 2002). The control variety for tropicaljaponica rice was Kalimutu. It was rice variety introduced from Kenya having drought resistance characteristic (Silitonga 2010). These rice paddy varieties were first sown in five plastic boxes which contains 20 rice varieties each. Fourteen days later seedlings were transplanted into a set of boxes containing natural paddy soil. Rice plants were grown under greenhouse maintenance.

\section{Molecular Analysis}

DNA was extracted using Dellaporta (1983) method. Individual Polymerase Chain Reaction was performed in $20.0 \mu \mathrm{L}$ of a mixture containing $5 \mu \mathrm{L}(10 \mathrm{ng} / \mu \mathrm{L})$ DNA template of each sample, $1.2 \mu \mathrm{L}(5 \mathrm{M})$ CEQ-compatible fluorescentlabeled primer pairs, $2 \mu \mathrm{L}$ of dNTP mix $(2.5 \mathrm{mM})$, $2 \mu \mathrm{L}$ 10X PCR buffer and $0.2 \mu \mathrm{L}$ Roche FastStart Taq DNA Polymerase kit 5 units/ $\mu \mathrm{L}$. The PCR machine of DNA Engine Tetrad2 Peltier Thermal Cycler MJ Research was run in program following touchdown procedure which consisted of 4 minutes initial denaturation step at $95{ }^{\circ} \mathrm{C}$, 13 cycles touchdown at $-0.5^{\circ} \mathrm{C}$ increments, 45 seconds at $95^{\circ} \mathrm{C}, 45$ seconds at $61.5^{\circ} \mathrm{C}$ decreased by $0.5^{\circ} \mathrm{C}$ every cycle, 30 seconds at $72^{\circ} \mathrm{C}$, followed by 27 cycles at 45 seconds at $95^{\circ} \mathrm{C}, 45$ seconds at $55{ }^{\circ} \mathrm{C}, 30$ seconds at $72{ }^{\circ} \mathrm{C}$ and a final extention step for 5 minutes at $72{ }^{\circ} \mathrm{C}$. The automatic capillary electrophoresis was used to separate and visualize the PCR products following procedures recommended by the manufacturer (Beckman 2004).

\section{Data Analysis}

The SSR fragment analysis was based on the allele sizes generated and implemented in PowerMarker V3.25 (Liu \& Muse 2005) that calculated the allele frequency, gene diversity and Polymorphism Information Content (PIC). The population structure of the rice accessions was calculated using Structure v3.2 (Pritchard et al. 2000). The posterior probabilities were estimated assuming prior values of $k$ between 1 and 8 using the Markov Chain Monte Carlo method (MCMC). The results of this study were based on burn-in period length of 10,000; MCMC iteration after burn-in of 100,000; with twenty replications. The degree of admixture, alpha, was inferred from the data. When alpha is close to zero, most individuals are essentially from one population or another; whereas when alpha $>1$, this means that 
most individuals are admixed (Falush et al. 2003). The $k$ value was determined by $\mathrm{LnP}(\mathrm{D})$ in STRUCTURE output and delta $k$ based on the rate of change in $\mathrm{LnP}(\mathrm{D})$ between successive $k$ (Evanno et al. 2005). Both $\operatorname{LnP}(\mathrm{D})$ in STRUCTURE output and its derived delta $k$ were used to determine the $k$ value. To determine the putative association between agro-morphological characterization and the SSR markers it was run on Mixed Linear Model (MLM) method in TASSEL (Bradbury et al. 2007). The $p$ value calculated by TASSEL determined whether a QTL was associated with the marker. Of the several methods suggested to correct false positive in association analysis, even keeping stringent $p$ value benchmark, the most stringent correction method called "Bonferroni Correction" was used in the present study. The threshold was found to be $7.1 \times 10^{-4}$ at significance level of $1 \%$ after Bonferroni multiple test correction $(0.01 / 14)$.

\section{Agro-Morphological Characteristic}

The accessions were characterized according to descriptors established by Silitonga et al. (2003). A total of 13 qualitative and 9 quantitative descriptors were used. The qualitative descriptors were: auricle color, ligule colour, ligule shape, leaf type, flag leaf attitude, collar color, culm color, culm habit, panicle exertion, panicle type, apiculus color, lemma and palea color and thresh ability. The quantitative descriptors were: plant height, total number of tiller, number of effective tiller, panicle length, number of panicle, number of fertile grain, number of sterile grain, grain percentage of sterility and 1,000 grain weight. Descriptive analysis was used to calculate the quantitative descriptors. Genetic variability of observed characters was calculated using Anderson and Bancroft (1952) formula. Genetic variability is broad when $\sigma_{\mathrm{G}}{ }_{\mathrm{G}} \geq 2\left(\sigma_{\mathrm{G}}\right)$ and narrow when $\sigma_{G_{G}}^{2}<2\left(\sigma_{G}\right)$. The qualitative descriptors analyzed were determined by Principal Coordinate Analysis (PCoA) generated from NTSYSpc 2.11p to create a scatter plot showing genetic relationships among accessions.

\section{RESULTS AND DISCUSSION}

\section{SSR Fragment Analysis}

A total of 140 alleles, with an average of 10 alleles per locus were detected at the 14 SSR loci. The number of alleles per locus ranged from 4 i.e. RM484 and RM124 to as many as 17 i.e. RM474. RM484 presented the smallest allele size range (4 bp), while RM250 had the largest allele size range (74 bp). Polymorphism Information Content (PIC) values were high for most of the microsatellites, averaging 0.73 and ranging from a low of 0.54 i.e. RM484 to a high of 0.89 i.e. RM541. RM250 presented the highest frequency allele up to $62 \%$. RM541 and RM144 showed the lowest frequency alleles, $17 \%$ and $19 \%$, respectively (Table 1).

Table 1 List of Indonesian rice landraces and improved varieties used in this study

\begin{tabular}{|c|c|c|c|c|c|c|c|}
\hline No & Reg. & Accession & Source & No. & Reg. & Accession & Source \\
\hline 1 & 3303 & Slamet & Lampung & 49 & 20628 & Kalimutu & $\begin{array}{l}\text { Introduction from } \\
\text { Kenya }\end{array}$ \\
\hline 2 & 3981 & Loneng & West Kalimantan & 50 & 20743 & Mama Wangi Kero & East Nusa Tenggara \\
\hline 3 & 3983 & Reli & West Kalimantan & 51 & 20747 & Madha Kedhi & East Nusa Tenggara \\
\hline 4 & 4355 & Ase Djambe & South Sulawesi & 52 & 21377 & Padai Pulut Melayang & East Kalimantan \\
\hline 5 & 4363 & Ase Bolong A & South Sulawesi & 53 & 20773 & Nalu Lepu & East Nusa Tenggara \\
\hline 6 & 4365 & Ase Puteh & South Sulawesi & 54 & 20798 & Dinu Toru & East Nusa Tenggara \\
\hline 7 & 5575 & Bulan Sabit & $\begin{array}{l}\text { East Nusa } \\
\text { Tenggara }\end{array}$ & 55 & 20831 & Toliwang IV & Maluku \\
\hline 8 & 5634 & Gedangan & East Java & 56 & 20919 & Cirata & Improved variety \\
\hline 9 & 5652 & Pelangan & Central Java & 57 & 21313 & Batutegi & Improved variety \\
\hline 10 & 19999 & $\begin{array}{l}\text { Padai Pulut } \\
\text { Ayang }\end{array}$ & East Kalimantan & 58 & 21002 & Sibuyung Pendek & East Kalimantan \\
\hline 11 & 5665 & Gotera & Central Java & 59 & 21003 & Padi Merah & East Kalimantan \\
\hline 12 & 5720 & Tholo & Central Java & 60 & 21021 & Pulut olan & East Kalimantan \\
\hline
\end{tabular}


Table 1 Continued

\begin{tabular}{|c|c|c|c|c|c|c|c|}
\hline No & Reg. & Accession & Source & No. & Reg. & Accession & Source \\
\hline 13 & 6293 & Si Hadap & West Sumatera & 61 & 21415 & Padai Oko Bat & East Kalimantan \\
\hline 14 & 6768 & Serendeh & Lampung & 62 & 21050 & Pait & East Kalimantan \\
\hline 15 & 6790 & $\begin{array}{l}\text { Palembang } \\
\text { Kuning }\end{array}$ & Lampung & 63 & 19871 & Padi Ketumbar & West Kalimantan \\
\hline 16 & 7885 & Umbang Bilis & $\begin{array}{l}\text { Central } \\
\text { Kalimantan }\end{array}$ & 64 & 21057 & Bawi & East Kalimantan \\
\hline 17 & 8000 & Serlak & South Sumatera & 65 & 19936 & Gropak & Central Java \\
\hline 18 & 8052 & $\begin{array}{l}\text { Kemandi } \\
\text { Pance }\end{array}$ & South Sulawesi & 66 & 21075 & Ketan Mayang & East Kalimantan \\
\hline 19 & 8065 & Padi Kuda & Jambi & 67 & 21087 & P. Ajatn & East Kalimantan \\
\hline 20 & 8081 & Si Bujang Putih & South Sumatera & 68 & 21157 & G.02 & Improved variety \\
\hline 21 & 8116 & Gando & South Sumatera & 69 & 21357 & Padai Mahak & East Kalimantan \\
\hline 22 & 8125 & $\begin{array}{l}\text { Padi Agai } \\
\text { Pandak }\end{array}$ & South Sumatera & 70 & 21191 & Pemangkat & West Kalimantan \\
\hline 23 & 8126 & Padi Amir & South Sumatera & 71 & 21152 & Sintanur & Improved variety \\
\hline 24 & 21266 & Buntut Kasar & West Kalimantan & 72 & 21225 & Padi Dewi & West Kalimantan \\
\hline 25 & 8192 & Si Cantik & NAD & 73 & 21228 & Tayan & West Kalimantan \\
\hline 26 & 8656 & Padi Aceh & Riau & 74 & 21230 & Segeret & West Kalimantan \\
\hline 27 & 15153 & Pare Lambem & $\begin{array}{l}\text { East Nusa } \\
\text { Tenggara }\end{array}$ & 75 & 21328 & Konawe & Improved variety \\
\hline 28 & 15200 & Padi Jerming & $\begin{array}{l}\text { West Nusa } \\
\text { Tenggara }\end{array}$ & 76 & 21260 & Bilak & West Kalimantan \\
\hline 29 & 19066 & B57C-Md-10-2 & Improved variety & 77 & 21261 & Ketupat & West Kalimantan \\
\hline 30 & 19193 & BPI-76 & Improved variety & 78 & 21262 & Pance & West Kalimantan \\
\hline 31 & 19670 & Singkarak & Improved variety & 79 & 21265 & Ringkak Siman & West Kalimantan \\
\hline 32 & $19907 \mathrm{c}$ & $\begin{array}{l}\text { Padi Lima } \\
\text { Bulan }\end{array}$ & West Kalimantan & 80 & 21267 & Ringka Kasir & West Kalimantan \\
\hline 33 & 20306 & Meulaboh & NAD & 81 & 21268 & Ketumbar & West Kalimantan \\
\hline 34 & 20377 & Misik A & $\begin{array}{l}\text { Central } \\
\text { Kalimantan }\end{array}$ & 82 & 21325 & IR Kebo & West Java \\
\hline 35 & 20387 & Unggul Sawah & $\begin{array}{l}\text { Central } \\
\text { Kalimantan }\end{array}$ & 83 & 21338 & Silugonggo & Improved variety \\
\hline 36 & 20389 & Jaka & $\begin{array}{l}\text { Central } \\
\text { Kalimantan }\end{array}$ & 84 & & INPARI-1 & Improved variety \\
\hline 37 & 20390 & Gading Garu & $\begin{array}{l}\text { Central } \\
\text { Kalimantan }\end{array}$ & 85 & & INPARI-2 & Improved variety \\
\hline 38 & 20394 & Kumpang Emas & $\begin{array}{l}\text { Central } \\
\text { Kalimantan }\end{array}$ & 86 & & INPARI-3 & Improved variety \\
\hline 39 & 20410 & Talun Bajang & $\begin{array}{l}\text { Central } \\
\text { Kalimantan }\end{array}$ & 87 & & INPARI-4 & Improved variety \\
\hline 40 & 20413 & K.Sampi Hiling & $\begin{array}{l}\text { Central } \\
\text { Kalimantan }\end{array}$ & 88 & & INPARI-8 & Improved variety \\
\hline 41 & 20442 & Talun Bura & $\begin{array}{l}\text { Central } \\
\text { Kalimantan }\end{array}$ & 89 & & INPARI-9 & Improved variety \\
\hline 42 & 20445 & Pontianak C & $\begin{array}{l}\text { Central } \\
\text { Kalimantan }\end{array}$ & 90 & & INPARI-10 & Improved variety \\
\hline 43 & 20448 & Satum & $\begin{array}{l}\text { Central } \\
\text { Kalimantan }\end{array}$ & 91 & & INPARI-11 & Improved variety \\
\hline 44 & 21272 & Ringkak Sa'dan & West Kalimantan & 92 & & INPARI-12 & Improved variety \\
\hline 45 & 20523 & Umbang Pulai & $\begin{array}{l}\text { Central } \\
\text { Kalimantan }\end{array}$ & 93 & & INPARI-13 & Improved variety \\
\hline 46 & 20528 & Pulut Silu & $\begin{array}{l}\text { Central } \\
\text { Kalimantan }\end{array}$ & 94 & & INPAGO-4 & Improved variety \\
\hline 47 & 20556 & Sebaung & $\begin{array}{l}\text { Central } \\
\text { Kalimantan }\end{array}$ & 95 & & INPAGO-5 & Improved variety \\
\hline 48 & 20627 & Jatiluhur & Improved variety & 96 & & INPAGO-6 & Improved variety \\
\hline
\end{tabular}


SSR markers generate multi allelic data revealing genetic structure of a natural population consisting of diverse genotypes (Remington et al. 2001). This study, using 96 Indonesian rice accessions, revealed a total of 140 alleles detected from 14 SSR loci. This finding was lower compared to the study results obtained by Thomson et al. (2007) who detected 394 alleles at 30 SSR loci across 330 rice accessions. However, abundant genetic variation in this study was identified with an overall gene diversity of 0.75 and average of 10 alleles per locus (Tabel 2) compared to an overall gene diversity of 0.68 and average of 11.9 alleles per locus (Thomson et al. 2007).

Polymorphism Information Content (PIC) values, a reflection of allele diversity and frequency among the varieties, averaged 0.73 and ranged from a low of 0.54 to a high of 0.89 compared to results obtained from the study carried out by Thomson et al. (2007). The PIC values ranged from 0.34 to 0.88 (RM154 and RM474), with an average of 0.66. Different results of this study and the study conducted by Thomson et al. (2007) might be caused by different sampling strategies, due to different provinces, different numbers of provinces and different numbers of SSR markers used by the two studies).

\section{Population Structure}

Fourteen SSR markers were distributed on the rice genome to assess genetic architecture and population structure. It was observed that delta$\mathrm{K}$ declined after $k=5$ was continuously significant, suggesting the presence of five subgroups (Fig. 1).

At $k=5$, most accessions were classified into five groups, which corresponded to indica- 1 with 20 consisted of improved varieties, traditional rice sub-species japonica with 13 accessions, indica2 with 21 germplasm accessions, indica- 3 with 24 germplasm accessions and indica-4 with 18 germplasm accessions and no admixture population was found. The degree of admixture (alpha) generated in this study was close to zero (0.04) which means most individuals are essentially from one population.

Analysis of population structure identified the highest log likelihood and delta $k$ with the number

Table 2 Data summary for 14 fluorescent-labeled microsatellite markers across 96 rice accessions

\begin{tabular}{|c|c|c|c|c|c|c|c|c|c|c|}
\hline \multirow[b]{2}{*}{ Panel } & \multirow[b]{2}{*}{ Dye $^{\mathrm{a}}$} & \multirow[b]{2}{*}{ Marker } & \multirow[b]{2}{*}{ Chr } & \multirow[b]{2}{*}{ Motif ${ }^{b}$} & \multirow[b]{2}{*}{$\begin{array}{l}\text { No.of } \\
\text { Allele }\end{array}$} & \multirow[b]{2}{*}{ Range } & \multirow[b]{2}{*}{$\begin{array}{c}\text { Gene } \\
\text { diversity }\end{array}$} & \multicolumn{2}{|c|}{ Major Allelec } & \multirow[b]{2}{*}{$\mathrm{PIC}^{\mathrm{d}}$} \\
\hline & & & & & & & & $\begin{array}{l}\text { Size } \\
\text { (bp) }\end{array}$ & $\begin{array}{c}\text { Frequency } \\
(\%)\end{array}$ & \\
\hline 1 & D3 & RM484 & 10 & $(\mathrm{AT}) 9$ & 4 & $292-296$ & 0.59 & 294 & 58 & 0.54 \\
\hline 1 & D4 & RM105 & 9 & (CCT) 6 & 7 & $100-137$ & 0.79 & 133 & 30 & 0.76 \\
\hline 1 & D4 & RM536 & 11 & $(\mathrm{CT}) 16$ & 10 & 218-259 & 0.60 & 232 & 60 & 0.58 \\
\hline 2 & D3 & RM124 & 4 & (TC)10 & 4 & $266-272$ & 0.63 & 268 & 51 & 0.56 \\
\hline 2 & D4 & RM162 & 6 & $(\mathrm{AC}) 20$ & 12 & $204-250$ & 0.84 & 210 & 31 & 0.83 \\
\hline 2 & D4 & RM277 & 12 & $(\mathrm{GA}) 11$ & 8 & $112-137$ & 0.72 & 121 & 45 & 0.68 \\
\hline 3 & D3 & RM287 & 11 & $(\mathrm{GA}) 21$ & 11 & $93-157$ & 0.83 & 113 & 26 & 0.80 \\
\hline 3 & D3 & RM259 & 1 & (CT)17 & 14 & 119-179 & 0.79 & 154 & 34 & 0.77 \\
\hline 3 & D4 & RM250 & 2 & (CT)17 & 10 & 119-193 & 0.59 & 171 & 62 & 0.57 \\
\hline 3 & D4 & RM514 & 3 & $(\mathrm{AC}) 12$ & 12 & $240-274$ & 0.80 & 249 & 29 & 0.77 \\
\hline 4 & D3 & RM541 & 6 & (TC)16 & 14 & $131-198$ & 0.90 & 182 & 17 & 0.89 \\
\hline 4 & D3 & RM144 & 11 & $\left(\mathrm{ATT}^{\circ}\right) 11$ & 11 & $220-286$ & 0.88 & 220 & 19 & 0.87 \\
\hline 4 & D4 & RM474 & 10 & (AT)13 & 17 & $228-299$ & 0.88 & 229 & 25 & 0.87 \\
\hline 4 & D4 & RM171 & 10 & (GATG)5 & 6 & $321-345$ & 0.70 & 341 & 48 & 0.67 \\
\hline
\end{tabular}

${ }^{a}$ Fluorescent dyes for CEQ Beckman Genetic Analyzer: D2 = Black, D3 = Green, and D4 = Blue

${ }^{b}$ Motif of the SSR and number of repeats as previously published (http://www.gramene.org)

'Major allele is defined as the allele with the highest frequency

${ }^{\mathrm{d}} \mathrm{PIC}=$ Polymorphism Information Content 


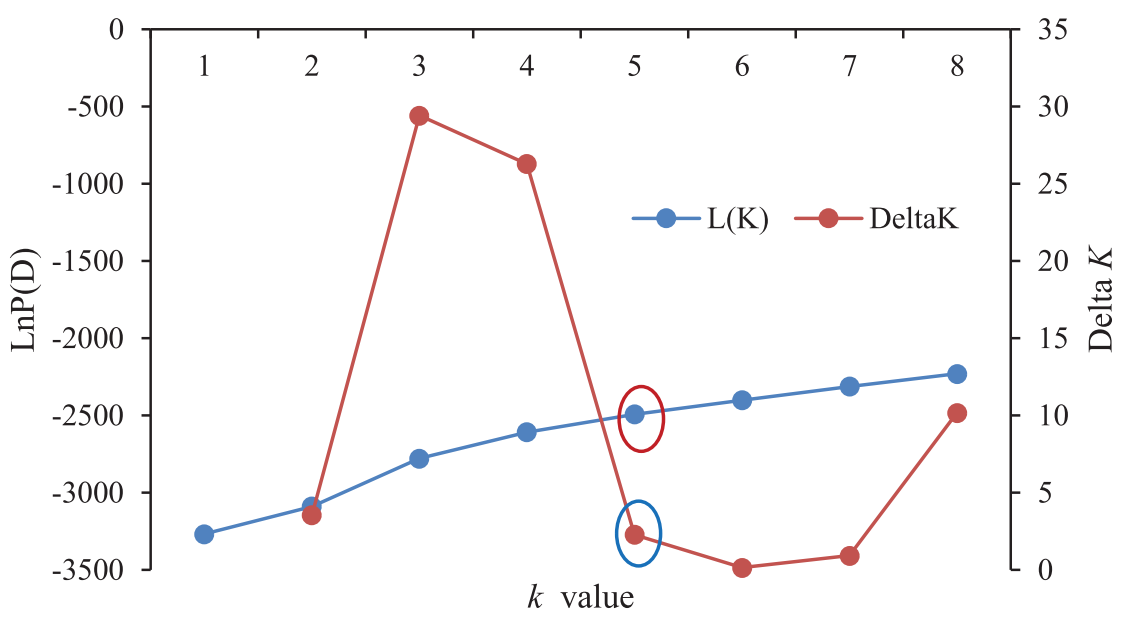

Figure 1 The presence of $k=5$ based on posterior probability, $\mathrm{L}(K)$ and delta $K$ where $k$ ranged from $1-8$

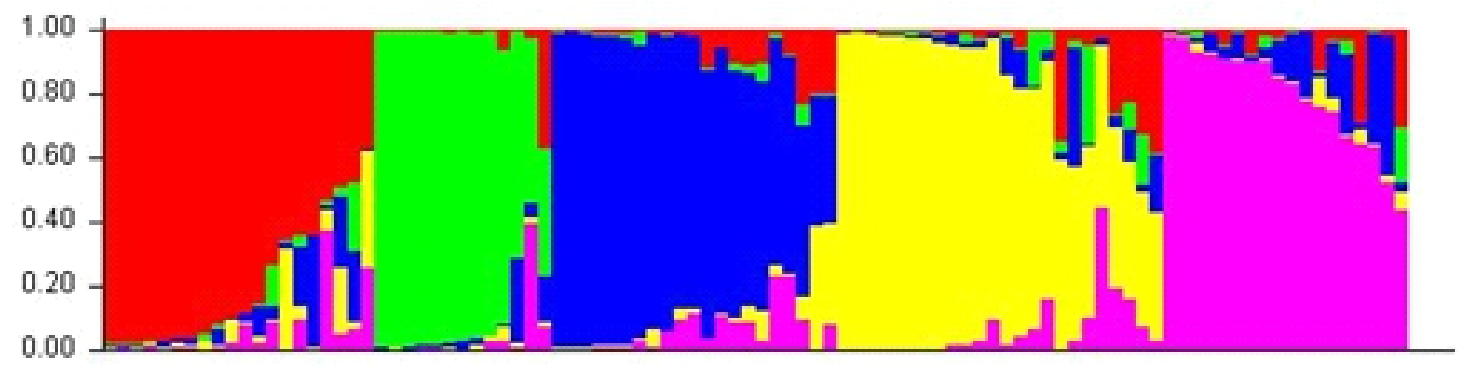

Figure 2 Bar plot representing population structure of five subgroups of Indonesian rice in this study. Red $=$ Indica-1 (Improved varieties), Green= Japonica, Blue $=$ Indica -2 (germplasm), Yellow=Indica-3 (germplasm), and Pink $=$ Indica-4 (germplasm)

of populations set at five $(k=5)$. These five populations corresponded to one tropical japonica population $(13.5 \%)$ and four indica populations and no admixture population was identified. These four subgroups corresponded to Indonesian improved varieties in subgroup 1 $(20.8 \%)$, rice landraces in subgroup $3(21.8 \%)$ and subgroup 4 (25\%) and subgroup 5 (18.7\%) (Fig. 2).

These results were quite different from previously analyzed population structure at $k=2$ of 330 Indonesian rice varieties with 30 microsatellite markers that divided Indonesian germplasms into indica and tropical japonica (Thomson et al.2007). The $k=2$ setting forced all accessions into two populations, causing the more distant related groups, such as the O. rufipogon and aus accessions, to appear as admixtures between indica and japonica. Khush et al. (2003) analyzed 3,670 Indonesian varieties with 11 isozymes and found out that $69 \%$ of the sampled Indonesian germplasms as indica, 28\% as japonica and 3\% as intermediates. However, it was difficult to make any distinctions between landraces and improved varieties.

\section{Agro-Morphological Characteristic}

PCoA analysis classified the 13 qualitative agro-morphological characteristics into three groups, which corresponded to the traditional rice subspecies tropical japonica with 19 accessions, indica-1 with 23 germplasm accessions and indica- 2 with 54 improved varieties and germplasm accessions (Fig. 3).

This result was different from the SSR analysis which classified the characteristics into five groups. The SSR results divided the third group in agro-morphological characteristic into three groups which separated the indica (group 1) from improved varieties and indica (group 3 and 5) from germplasm accessions. The descriptive analysis of 9 quantitative descriptors of 96 Indonesian rice accessions is presented in Table 3. The broad variability of quantitative morphological character was found in all 9 quantitative descriptors. Genetic variability is considered 


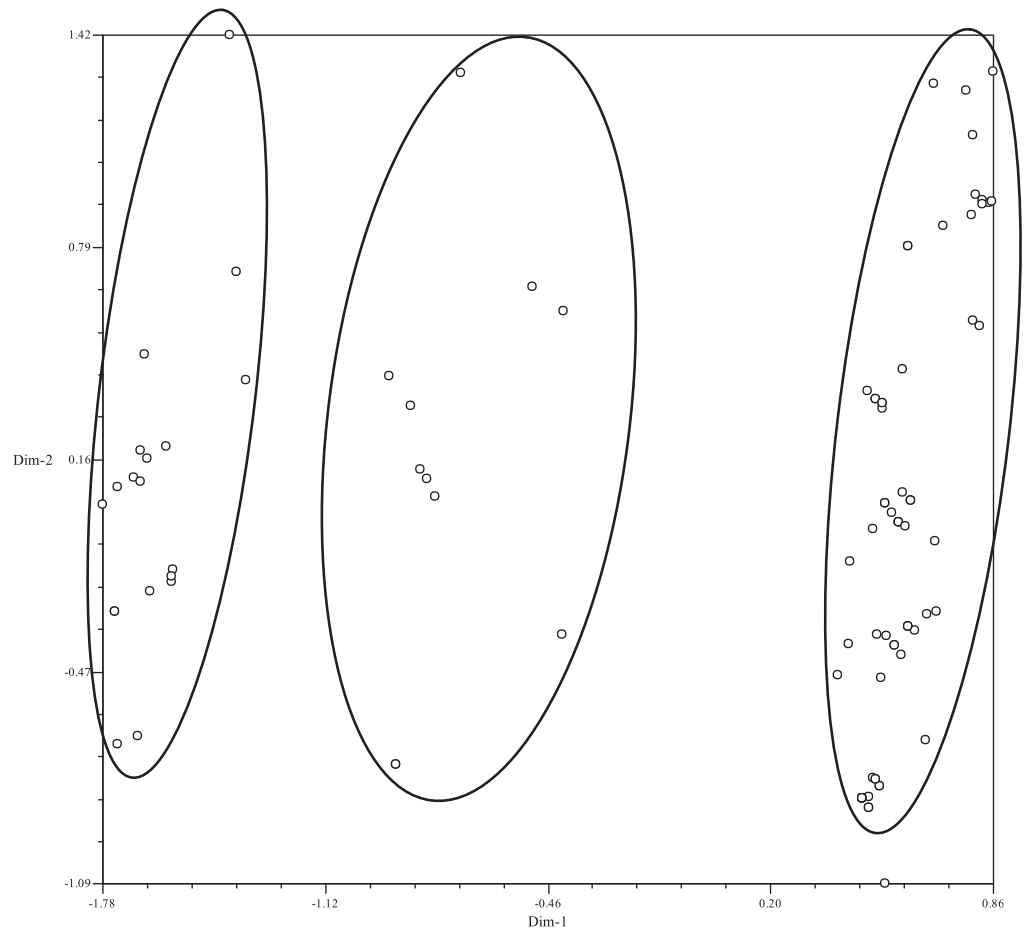

Figure 3 The PCoA analysis based on 13 qualitative agro-morphological characteristics classified into three groups, which corresponded to the traditional rice sub-species japonica (19 accessions), indica-1 (23 accessions) consisted of germplasm accessions and indica-2 (54 accessions) consisted of improved varieties and germplasm accessions

broad when $\sigma_{G}^{2} \geq 2\left(\sigma_{\mathrm{G}}\right)$ and narrow when $\sigma_{\mathrm{G}}^{2}<2\left(\sigma_{\mathrm{G}}\right)$ (Anderson \& Brancoft 1952).

Based on the culm habit there were 5 types of characteristics however we found 3 types in these rice germplasm i.e.: erect $\left(15^{\circ}\right)$, semi erect/intermediate $\left(20^{\circ}\right)$, and open $\left(40^{\circ}\right)$. In this study, the 96 accessions were divided into 3 characteristics i.e. erect $(78 \%)$, semi-erect $(21 \%)$ and open $(1 \%)$. From these, the cultivated rice varieties were divided into 2 characteristics i.e. erect $(83 \%)$ and semi-erect $(17 \%)$ while Indonesian rice landraces were divided into 3 characteristics i.e. erect $(76.4 \%)$, semi-erect $(22.2 \%)$ and open $(1.4 \%)$. Similar with Rabara et al. (2014) mentioned that most of the traditional rice varieties in Philippines had thick culms and an erect culm habit. Regarding for improving yield, Wu et al. (2011) shown that large culm rice varieties have a higher number of grains per panicle and a longer spike length. Gealy et al.

Table 3 Descriptive analysis of quantitative descriptors of 96 Indonesian rice

\begin{tabular}{lccccccccc}
\hline Character & Min & Max & Range & Means & SD & SE & Variance & Skewness & Kurtosis \\
\hline PH & 84.7 & 195.3 & 110.6 & 129.87 & 28.46 & 2.90 & 809.80 & 0.00 & -0.99 \\
TT & 4 & 16 & 12 & 7.95 & 2.49 & 0.25 & 6.20 & 1.33 & 1.72 \\
NET & 4 & 13 & 9 & 6.82 & 2.08 & 0.21 & 4.32 & 1.10 & 0.99 \\
PL & 14.8 & 35.7 & 20.9 & 23.33 & 3.89 & 0.40 & 15.17 & 0.44 & 0.75 \\
NP & 2 & 23 & 21 & 5.46 & 2.50 & 0.26 & 6.26 & 3.82 & 24.69 \\
NGF & 1.3 & 482 & 480.7 & 100.36 & 67.86 & 6.96 & $4,604.61$ & 2.17 & 9.46 \\
NSG & 4.7 & 258 & 253.3 & 52.32 & 39.47 & 4.05 & $1,557.70$ & 2.15 & 7.40 \\
PcS & 6 & 97.3 & 91.3 & 34.86 & 17.50 & 1.80 & 306.09 & 0.90 & 1.02 \\
ToGW & 12 & 37.9 & 25.9 & 21.00 & 4.31 & 0.44 & 18.60 & 0.64 & 1.93
\end{tabular}

Notes: $\mathrm{PH}=$ Plant Height, $\mathrm{TT}=$ Total Number of Tiller, NET=Number of Effective Tiller, $\mathrm{PL}=$ Panicle Length, NP=, Number of Panicle, NGF $=$ Number of Fertile Grain, NSG $=$ Number of Sterile Grain, PcS $=$ Percentage of Sterility, ToGW=Total 1,000 Grain Weight 
(2006) and Hussain et al. (2010) reported that the presence of erect plant types could be due to backcrossing between accessions or with commercial rice cultivar.

The culm color was characterized as light gold $(92 \%)$ and green $(8 \%)$, while the cultivated accessions were characterized as light gold. The collar color from the 96 accessions was characterized as light green $(95 \%)$ and purple (5\% i.e. Bulan Sabit, Gedangan, Loneng, Padi Kuda, and Pulut Silu). The cultivated accessions were characterized as light green. The ligule color from the 96 accessions was characterized as absent $(93 \%)$, purple lines $(5 \%)$ and purple $(2 \%)$, while the cultivated accessions were characterized as absent. The auricle color from the 96 accessions were characterized as absent $(83 \%)$, purple lines $(16 \%)$ and purple (1\% i.e. Gedangan and Toliwang IV), while the cultivated accessions were characterized as absent.

The flag leaf attitude from the 96 accessions were characterized as $28 \%$ erect, $49 \%$ semi erect, $3 \%$ horizontal and $20 \%$ descending, in which the cultivated accessions were in erect category. Dewi et al. (2009) mentioned that the erect flag leaf was more desirable than the horizontal one due to the higher sunlight intercept and might have a positive correlation with the high yield. Narayanan et al. (2007) reported that flag leaf as the major source of phloem-delivered photo assimilates during the grain-filling stage in rice and Khalifa et al. (2008) showed that cutting of flag leaves result to $45 \%$ grain yield loss.

There were 5 panicle types (attitude) i.e. erect (compact panicle), semi-erect (semi-compact panicle), spread (open panicle), horizontal and drooping. The 96 accessions category were $93 \%$ semi-erect and $7 \%$ spreading, in which the cultivated accessions were in semi-erect category. The means for panicle number per plant was 5.4 from 96 accessions (Table 3). For the cultivated varieties, the mean panicle number was 5.1 , in which Inpari 11 had the highest panicle number (23). The mean panicle number for Indonesian rice landraces was 5.6, in which Padai Agak Pandak had the highest panicle number (11). The mean for panicle length was $23.3 \mathrm{~cm}$ from 96 accessions (Table 3 ). For the cultivated varieties, the mean panicle length was 21, in which Inpago 4 had the longest panicle length $(34.7 \mathrm{~cm})$. The mean panicle length for Indonesian rice landraces was 24.1, in which Ketan Mayang had the longest panicle length $(35.7 \mathrm{~cm})$. Peng et al. (2014) reported that panicle structure is one of the most important factors for rice yield and panicle branches and their number affects spikelet number. Dense panicle structure has been a major target for improvement of rice grain yield because of its relationship with grain number.

The recorded mean for plant height in 96 accessions was $179.9 \mathrm{~cm}$, with a minimum height of $84.7 \mathrm{~cm}$ for Inpari 3, $85.7 \mathrm{~cm}$ for Madha Kedhi and a maximum of $195.3 \mathrm{~cm}$ for Bulan Sabit accession (Table 3). From the 96 accessions 31.3\% was dwarf $(80-110 \mathrm{~cm}), 17.7 \%$ was semi-dwarf $(110-130 \mathrm{~cm})$ and $51 \%$ was tall $(130-200 \mathrm{~cm})$ (Fig. 4). For the cultivated varieties, the mean height was $102 \mathrm{~cm}$, which the distribution were dwarf $(31.3 \%)$, semi-dwarf $(17.7 \%)$ and tall (51\%). The differences in the heights of the accessions were possibly due to various internodal lengths. The varieties having longer internodes produced
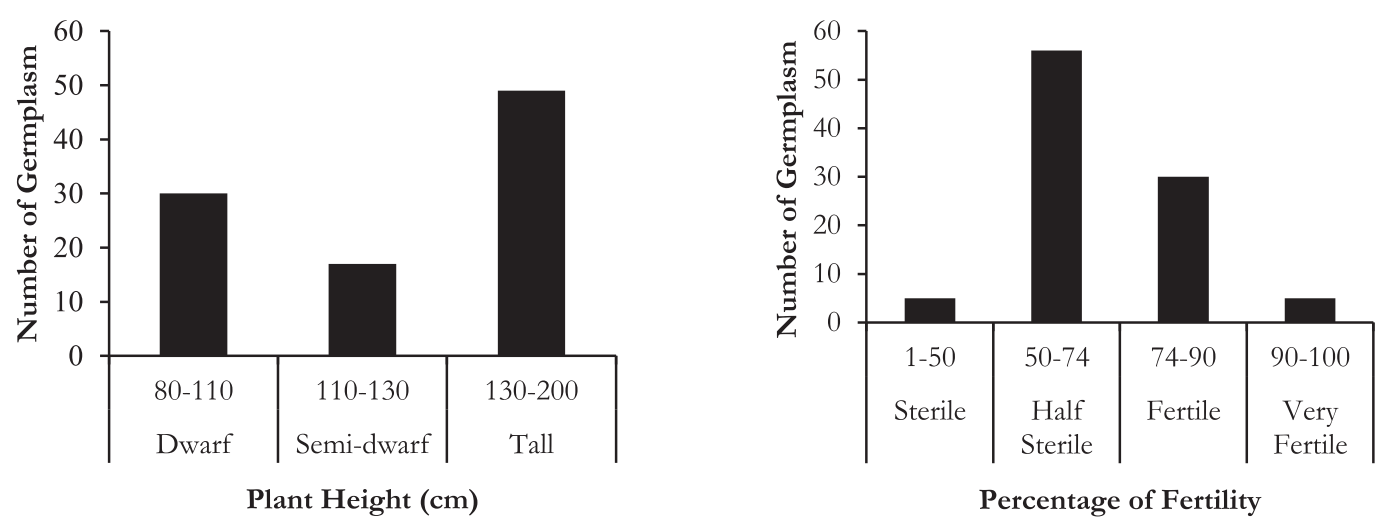

Figure 4 The agro-morphological characteristics based on plant height (left) and percentage of fertility (right) on 96 accessions 
Table 4 Marker-trait associations (MTAs) identified for select agronomic traits

\begin{tabular}{cllll}
\hline No & Trait & Marker & F Value & P Value \\
\hline 1 & Auricle color & RM105 & 4.4963 & $8.89 \mathrm{E}^{-05}$ \\
2 & Collar color & RM287 & 6.3796 & $1.09 \mathrm{E}^{-06}$ \\
3 & Ligule shape & RM105 & 4.8616 & $3.70 \mathrm{E}^{-05}$ \\
& & RM536 & 5.0657 & $1.61 \mathrm{E}^{-05}$ \\
& & RM514 & 5.3648 & $3.91 \mathrm{E}^{-06}$ \\
\hline
\end{tabular}

taller plants (Ashrafuzzaman et al. 2009; Hussain et al. 2014) and Mohammad et al. (2002) reported that plant height depends on genetic makeup of a plant and environmental conditions.

There were 4 types of fertility based on the percentage of fertility of the 96 accessions i.e. sterile $(5.2 \%)$, half sterile $(58.3 \%)$, fertile $(31.3 \%)$ and very fertile (5.2\%) (Fig. 4). The cultivated rice varieties were categorized as sterile $(0 \%)$, half sterile (75\%), fertile (20.8\%) and very fertile (4.2\% i.e. Sintanur). Indonesian rice landraces were categorized as sterile $(6.9 \%)$, half sterile $(47.2 \%)$, fertile (40.4\%) and very fertile (5.5\% i.e. Gando, Padi Dewi, Talun Bajang and Ringkak Siman). Kwon et al. (2015) found that a deficiency of SLR1 activity causes different spikelet fertility phenotypes in two different cultivars, Koshihikari and $\mathrm{H} 143$ which $\mathrm{H} 143$ exhibits partial sterility of spikelets while Koshihikari has normal fertility. Liu et al. (2013) mentioned that spikelet fertility is a critical yield-determining trait that is influenced by genetic background and environmental factors including rain, wind, and temperature. Anther development and pollen viability particularly affect spikelet fertility.

\section{Association Analysis}

A total of 4 marker-trait associations were identified with 14 different SSR markers (Table 4).

Based on agro-morphological characters, one character with highly significant MTA was number of panicle associated with RM277 on chromosome 12. Liu et al. (2008) identified QTL for primary branch number in panicle $(q P B N-\sigma)$ on chromosome 6 in the interval of RM3 RM162. Mu et al. (2005) and Liu et al. (2008) explained that the primary branch number per panicle was determined by the initial size of the reproductive apex. The floret number per primary branch was determined by the cell division activity. Thicker panicle neck development and larger panicle came from the parallel development during the panicle initiation, or floret developing. Grain filling were enhanced by stronger transporting process of water and nutrients based on thicker panicle neck. Spikelet number was mostly determined during the panicle initiation, while the number and weight of filled grain were largely affected by the conductive tissue together with the source strength. Wickneswari et al. (2012) reported that RM259 and RM208 were used to identify QTL for grains per panicle as peak markers for $q G P P-1$ and $q G P P-2$, respectively.

Among the MTAs obtained in this study, some were similar as previously reported, indicating that these MTAs were reliable. These reliable MTAs were repeatable in different studies with various segregation population. Other MTAs had been probed for the first time, indicating that more information on QTLs could be found using populations of different genetic backgrounds. This is important for an in-depth understanding of the genetic control of yield traits in rice and for future rice production using molecular marker-assisted selection in rice breeding (Iqbal et al. 2003).

\section{CONCLUSIONS}

High resolution DNA banding pattern of the CEQ capillary gel electrophoresis system measured genetic variation of 96 rice varieties using 14 SSR markers, through population structure analysis. Taken together, the SSR markers identified in this study could be used for Marker-Trait Association (MTA) analysis of agromorphological characters. This study resulted to a 
total of 140 alleles with an average of 10 alleles per locus and Polymorphism Information Content (PIC) value at 0.73 . The population structure analysis identified five subgroups. A total of 4 highly significant MTA were identified. One character with highly significant MTA was number of panicle associated with RM277. Based on SSR marker, RM105 had two MTAs for auricle color and ligule shape. These MTAs may be deployed in improving rice productivity, after being validated.

\section{ACKNOWLEDGEMENTS}

We thank Jajat and Iban for greenhouse maintenance. This work was financially supported by DIPA ICABIOGRAD, Indonesian Ministry of Agriculture, Project number: 0118/018-09.2/XII to Tiur Sudiaty MS.

\section{REFERENCES}

Agrama HA, Eizenga GC, Yan W. 2007. Association mapping of yield and its components in rice cultivars. Mol Breeding 19:341-356.

Anderson RL, Bancroft TA. 1952. Statistical theory in research. NewYork (US): McGraw-Hill. 399p.

Ashrafuzzaman M, Islam MR, Ismail MR, Shahidullah SM, Hanafi MM. 2009. Evaluation of six aromatic rice varieties for yield and yield contributing characters. Int J Agric Bio 11:616-20.

Bajracharya J, Steele KA, Jarvis DI, Sthapit BR, Witcombe JR. 2006. Rice landrace diversity in Nepal: variability of agro-morphological traits and SSR markers in landraces from a high-altitude site. Fields Crop Res 95:327-35.

Beckman Coulter. 2004. CEQ genetic analysis system. User's guide. North Harbor Boulevard, Fullerton (US): Beckman Coulter, Inc. pp.4-14.

Blair MW, Hedetale V, McCouch SR. 2002. Fluorescentlabeled microsatellite panels useful for detecting allelic diversity in cultivated rice (Oryza sativa L.). Theor Appl Genet. 105:449-57.

Bradbury PJ, Zhang Z, Kroon DE, Casstevens TM, Ramdoss Y. 2007. TASSEL: software for association mapping of complex traits in diverse samples. Bioinformatics 23:2633-5.

Bustamam M, Tabien RE, Suwarno A, Abalos MC, Kadir TS, Ona I, Bernardo M, Veracruz CM, Leung H. 2002. Asian rice biotechnology network: improving popular cultivars through marker-assisted backcrossing. Proceeding International Rice Congress, Beijing (CN), 16 - 20 September 2002. p1022.

Coburn JR, Temnykh SV, Paul EM, McCouch SR. 2002. Design and application of microsatellite marker panels for semiautomated genotyping of rice (Oryza sativa L.). Crop Sci. 42:2092-9.

Dellaporta S1, Woods J, Hicks JB. 1983. A plant DNA minipreparation: version II. Plant Mol Biol Rep $1: 19-21$.

Dewi IS, Trilaksana AC, Koesoemaningtyas T, Purwoko BS. 2009. Karakterisasi galur haploid ganda hasil kultur antera padi. Bult Plasm Nutf 15:1-12.

Evanno G, Regnaut S, Goudet J. 2005. Detecting the number of clusters of individuals using the software STRUCTURE: a simulation study. Mol Ecol 14:2611-20.

Falush D, Stephens M, Pritchard JK. 2003. Inference of population structure using multilocus genotype data: linked loci and correlated allele frequencies. Genetics 164:1567-87.

Garris AJ, Tai TH, Coburn JR, Kresovich S, McCouch S. 2005. Genetic structure and diversity in Oryza sativa L. Genetics 169:1631-1638.

Gealy DR, Yan W, Rutger JN. 2006. Red rice (Oryza sativa) plant types, affect growth, coloration, and flowering characteristics of first and second generation crosses with rice. Weed Technol 20:839-52.

Hussain ZPMD, Azmi M, Ahmad SO. 2010. Morphological study of the relationships between weedy rice accessions (Oryza sativa complex) and commercial rice varieties in Pulau Pinang rice granary area. Trop Life Sci Res 21:27-40.

Hussain S, Fujii T, McGoey S, Yamada M, Ramzan M, Akmal M. 2014. Evaluation of different rice varieties for growth and yield characteristics. J Anim Plant Sci 24:1504-10.

Iqbal MS, Ghafoor A, Qureshi AS, Ahmad Z. 2003. Genetic dissimilarities in cowpea (Vigna unguiculata (L.) Walp.) for protein peptides and their significance for quantitative traits loci. Pak J Bot 35:377-86.

Jain S, Jain R, McCouch SR. 2004. Genetic analysis of Indian aromatic and quality rice (Oryza sativa L.) germplasm using panels of fluorescently-labeled microsatellite markers. Theor Appl Genet 109:96577.

Khalifa AAB, Misra A, Salem AEAK. 2008. Effect of leaf cutting on physiological traits and yield of two rice cultivars. Afr J Plant Sci 2:147-50.

Khush GS, Brar DS, Virk PS, Tang SX, Malik SS, Busto GA, Lee YT, McNally R, Trinh LN, Jiang Y, Shata MAM. 2003. Classifying rice germplasm by isozyme polymorphism and origin of cultivated rice. In IRRI Discussion Paper No. 46. International Rice Research Institute, Los Banos. 
Kwon CT, Kim SH, Kim D, Paek NC. 2015. The rice floral repressor Early flowering1 affects spikelet fertility by modulating gibberellin signaling. Rice 8(23):1-11.

Li X, Yan W, Agrama H, Hu B, Jia L, Jia M, Jackson A, Moldenhauer K, McClung A, Wu D. 2010. Genotypic and phenotypic characterization on genetic differentiation and diversity in the USDA rice mini-core collection. Genetica 138:1221-30.

Lin MS. 1991. Genetic base of japonica rice varieties released in Taiwan. Euphytica 56:43-6.

Liu K, Muse S. 2005. Power Marker: an integrated analysis environment for genetic marker analysis. Bioinformatics 21:2128-9.

Liu GL, Mei HW, Yu XQ, Zou GH, Liu HY, Hu SP, Li MS, Wu JH, Chen L, Luo LJ. 2008. QTL analysis of panicle neck diameter, a trait highly correlated with panicle size, under well-watered and drought conditions in rice (Oryza sativa L.). Plant Sci 174:71-7.

Liu W, Zhang DC, Tang MF, Li DY, Zhu YX, Zhu LH, Chen CY. 2013. THIS1 is a putative lipase that regulates tillering, plant height, and spikelet fertility in rice. J Exp Bot 64:4389-402.

Lu H, Redus MA, Coburn JR, Rutger JN, McCouch SR, Tai TH. 2004. Population structure and breeding patterns of 145 US rice cultivars based on SSR marker analysis. Crop Sci 45:66-76.

Mu C, Nemoto K, You Z, Yamagishi J. 2005. Size and activity of shoot apical meristems as determinants of floret number in rice panicles. Plant Prod Sci 8:51-9.

Mohammad T, Deva W, Ahmad Z. 2002. Genetic variability of different plant and yield characters in rice. Sarhad J Agric 18:207-10.

Narayanan NN, Vasconcelos MW, Grusak MA. 2007. Expression profiling of Oryza sativa metal homeostasis genes in different rice cultivars using a cDNA macroarray. Plant Physiol Biochem 45:27786.

Nascimento WF, da Silva EF, Veasey EA. 2011. Agromorphological characterization of upland rice accessions. Genet Plant Breed 68:652-66.

Parikh M, Motiramani NK, Rastogi NK, Sharma B. 2012. Agro-morphological characterization and assessment of variability in aromatic rice germplasm. Bangladesh J Agr Res 37:1-8.

Peng Y, Zhenyu G, Bin Z, Chaolei L, Jie X, Banpu R, Jiang H, Guojun D, Longbiao G, Guohua L, Qian Q. 2014.
Fine mapping and candidate gene analysis of a major QTL for panicle structure in rice. Plant Cell Rep 33:1843-50.

Pritchard JK, Stephens M, Donnely P. 2000. Inference of population structure using multilocus genotype data. Genetics 155:945-59.

Rabara RC, Marilyn CF, Celia LD, Ma CVN, Gabriel OR. 2014. Phenotypic diversity of farmers traditional rice varieties in the Philippines. Agronomy 4:217-41.

Remington DL, Thornsberry JM, Matsuoka Y, et al. 2001. Structure of linkage disequilibrium and phenotypic associations in the maize genome. Proceedings of the National Academy of Sciences of the United States of America 98:11479-84.

Seetharam U, Thirumeni S, Paramasivam K. 2009. Estimation of genetic diversity in rice (Oryza sativa L.) genotypes using SSR markers and morphological characters. Afr J Biotechnol 8:2050-9.

Silitonga TS, Budiarti SG, Rais SA, Asadi. 2001. Sumber daya genetik untuk perbaikan dan perakitan varietas unggul baru tanaman pangan. Bul Plasm Nutfh $7: 26-34$.

Silitonga TS, Ida HS, Aan AD, Hakim K. 2003. Panduan sistem karakterisasi dan evaluasi tanaman padi. Departemen Pertanian, Badan Penelitian dan Pengembangan Pertanian, Komisi Nasional Plasma Nutfah. Sekretariat Komisi Nasional Plasma Nutfah. Bogor (ID). 58 p.

Silitonga TS. 2010. The use of biotechnology in the characterization, evaluation, and utilization of Indonesian rice germplasm. Agrobiogen 6:49-56.

Thomson MJ, Septiningsih EM, Fatimah S, Santoso TJ, Silitonga TS, McCouch SR. 2007. Genetic diversity analysis of traditional and improved Indonesian rice (Oryza sativa L.) germplasm using microsatellite markers. Theor Appl Genet 114:559-68.

Wickneswari R, Bhuiyan MAR, Sabu KK, Li SL, Thomson MJ, Narimah MK, Abdullah MZ. 2012. Identification and validation of quantitative trait locifor agronomic traits in advanced backcross breeding lines derived from Oryza rufipogon $\times$ Oryza sativa Cultivar Mr219. Plant Mol Biol Report 30:92939.

Wu LL, Liu ZL, Wang JM, Zhou CY, Chen K M. 2011. Morphological, anatomical, and physiological characteristics involved in development of the large culm trait in rice. Aust J Crop Sci 5:1356-63. 